\title{
Use of dietary supplements among Brazilian athletes
}

\author{
Uso de suplementos alimentares entre \\ atletas brasileiros
}

Hellen Clair Garcez NABUCO ${ }^{1}$

Vanessa Behrends RODRIGUES²

Wander Miguel de BARROS 3

Fabricio César de Paula RAVAGNANI ${ }^{4}$

Mariano Martínez ESPINOSA 5

Christianne de Faria Coelho RAVAGNANI ${ }^{6}$

\section{A B S T R A C T}

\section{Objective}

To investigate the prevalence and establish the profile of the consumption of dietary supplements among Brazilian athletes.

\section{Methods}

A total of 182 athletes of both genders from 20 different sports participated in this study. The athletes answered a questionnaire containing sociodemographic and sports-related questions and were interviewed about the consumption of dietary supplements.

\section{Results}

Forty seven percent of athletes reported having consumed at least one type of dietary supplement and 38\% said they use more than three different types of supplements concurrently. Whey protein was the most commonly

\footnotetext{
1 Instituto Federal de Educação, Ciência e Tecnologia de Mato Grosso, Departamento de Administração e Planejamento. Campus São Vicente, Rodovia BR-64, Km 329, Campo Verde, Cuiabá, MT, Brasil. Correspondência para/correspondência to: HCG NABUCO. E-mail: <hellencgarcez@gmail.com>.

2 Universidade Federal de Mato Grosso, Faculdade de Nutrição, Departamento de Alimentos e Nutrição. Cuiabá, MT, Brasil.

3 Instituto Federal de Educação, Ciência e Tecnologia de Mato Grosso, Departamento de Ensino, Programa de Pós-Graduação em Ciência e Tecnologia de Alimentos. Cuiabá, MT, Brasil.

${ }^{4}$ Instituto Federal de Educação, Ciência e Tecnologia de Mato Grosso, Departamento de Ensino, Pesquisa e Extensão. Cuiabá, MT, Brasil.

5 Universidade Federal de Mato Grosso, Instituto de Ciências Exatas e da Terra, Departamento de Estatística. Cuiabá, MT, Brasil.

${ }^{6}$ Universidade Federal de Mato Grosso, Departamento de Educação Física, Programa de Pós-Graduação em Educação Física. Cuiabá, MT, Brasil.

Support: Coordenação de Aperfeiçoamento de Pessoal Nível Superior and Conselho Nacional de Desenvolvimento Científico e Tecnológico (Process $\left.n^{\circ} 446323 / 2014-4\right)$.
} 
consumed supplement, and the most frequently mentioned reason for its consumption was performance improvement. The main source of information was coaches, and individual sport athletes were the greatest consumers and the most likely to seek dietary supplement.

\section{Conclusion}

Approximately half of the participants used dietary supplements, which on most occasions were recommended by coaches. The consumption profile also revealed multiple supplementation practice and showed that nutrition education is essential for this specific population.

Keywords: Athletes. Dietary supplements. Prevalence.

\section{R E S U M O}

\section{Objetivo}

Descrever a prevalência e o perfil de ingestão de suplementos alimentares entre atletas brasileiros.

\section{Métodos}

Participaram do estudo 182 atletas de ambos os sexos de 20 diferentes modalidades esportivas. Os atletas responderam a um questionário contendo informações sociodemográficas e esportivas e foram entrevistados quanto ao consumo de suplementos.

\section{Resultados}

Quarenta e sete porcento dos atletas relataram ter consumido pelo menos um tipo de suplemento e 38\% utilizavam mais de três tipos de suplementos concomitantemente. O suplemento mais consumido foi o whey protein e a razão mais citada para o consumo foi a melhora no desempenho físico. A maior fonte de informação foi o treinador, sendo os atletas de modalidades individuais os maiores consumidores e também os mais propensos a buscarem essa fonte.

\section{Conclusão}

Quase metade da amostra fazia uso de suplementos, os quais eram indicados, predominantemente, pelos treinadores. O perfil de consumo também revelou a prática da poli suplementação e mostra que a educação nutricional é essencial para essa população específica.

Palavras-chave: Atletas. Suplementos nutricionais. Prevalência.

\section{NTRODUCTION}

According to the Dietary Supplement Health and Education Act (DSHEA) of 1994, dietary supplements are products intended to supplement the diet and contain vitamins, minerals, herbs, amino acids, enzymes, and metabolites. They can be found in many forms such as tablets, capsules, soft gels, gel caps, powders, or liquids [1].

These products are frequently consumed by athletes $[2,3]$. The most frequently mentioned reasons given by athletes for the use of dietary supplements include increase in energy and strength, improvement in performance, maintenance or enhancement of overall health and the immune system, prevention of nutritional deficiencies, and also to speed injury recovery [4-7]. Aiming at obtaining these results, the most commonly consumed dietary supplements by this population are sports drinks, multivitamins and minerals, proteins, and amino acids [8].

However, aspects such as regulations, safety, and efficacy are of extreme importance for the choice of dietary supplements by professionals who recommend their use or by consumers. Dietary supplement use is a risk factor for illicit substance use [9], and they are associated with the risk of the so-called inadvertent doping since there may be positive results due to the contamination of their ingredients [10]. Another important aspect is that the effectiveness of several supplements on the market is controversial 
and questionable $[11,12]$. Their use should be recommended only by a qualified professional in specific circumstances, especially when there is restriction of energy or food intake [11].

Despite the growing concerns about harmful consequences on health and physical performance or risk of doping among athletes, the use of supplements in the sports world has increased with prevalence ranging from 37.5\% to $98.0 \%$ among athletes $[13,14]$, and elite athletes are the main consumers $[15,16]$. Moreover, most of them take more than one supplement daily $[4,6]$, and their family, coach, friends, and the Internet are their main sources for supplement choice $[6,17,18]$.

Although there are several studies on the prevalence of dietary supplement use among athletes from different sports $[2,5,8]$, there are few data regarding its use by Brazilian athletes $[19,20]$. National studies have investigated dietary supplementation practices among gym users [21], which may be different from the use patterns of athletes. Furthermore, few studies on athletes focus on issues related to the training volume, type of sport, and preparatory training phase. In addition, most of the studies available were carried out in developed countries, and thus they may not reflect Brazilian athletes' reality.

Considering the current participation of Brazil in the major sports events from around the world, it is important to know the patterns of dietary supplement use among professional athletes in order to propose specific interventions aimed at avoiding unnecessary and indiscriminate use of these products and promoting the development of elite sport in the country.

Therefore, the objectives of this study were: (a) to investigate the prevalence of dietary supplements use among Brazilian athletes; (b) to establish the profile of the consumption of these supplements including the reasons for use, types of supplements consumed, and source of information athletes seek.

\section{METHODS}

This is a cross-sectional study carried out at the Núcleo de Aptidão Física, Informática, Metabolismo, Esporte e Saúde (Nafimes, Center for Physical Fitness, Informatics, Metabolism, Sports, and Health) from December 2013 to October 2014. The sample was composed of 182 athletes of both genders, aged from 14 to 59 years, and who compete in 20 different sports (triathlon $=4 ; \quad$ cycling $=2$; swimming $=16$; bodybuilding $=19$; volleyball $=8$; soccer $=53$; futsal=6; beach volleyball=1; american football=7; Taekwondo=6; Karate=8; Judo=10; Kung Fu=7; Jiu-Jitsu=10; $M M A=6$; boxing=1; Muay Thai=1; track and field $=8$; and competitive shooting $=7$ ).

Convenience sampling was used, i.e., the participant athletes were selected based on availability and accessibility after contacting sports federations/clubs and coaches. Individuals who trained with competitive objectives and participated in regional and international events were considered athletes. All athletes and those responsible for athletes under the age of 18 years were informed of the study objectives and signed an Informed Consent Form. This study was approved by the Ethics Committee for Research on Humans of the Hospital Universitário Júlio Müller (Resolution n 488.198).

Data were collected via a self-administered questionnaire containing three different sections: 1) Biometric characteristics (gender and age); 2) Training characteristics (sport type, preparatory phase, and training volume); and 3) Use of dietary supplements (types of supplements, reasons for use, source of information, factors influencing the choice, and amount of supplements consumed). To confirm the accuracy of the dietary supplement questionnaire, a 24-hour dietary recall interview was conducted on two non-consecutive days in the same week the questionnaire was administered. The agreement between the two methods was measured using the Kappa coefficient, which was found to be satisfactory (0.72). The present study adopted the definition of dietary supplements 
according to the Dietary Supplement Health and Education Act [1] and Kreider et al. [22]. For the purposes of this study, federated athletes are those who belong to a sports federation of a given sport, and the preparatory phase is the training phase before competitions.

Body weight and height were measured using a scale with $100 \mathrm{~g}$ resolution and a portable stadiometer with a precision of $0.1 \mathrm{~cm}$, respectively, while the athletes were wearing light clothing and no shoes. Body Mass Index (BMI) was determined according to the World Health Organization (WHO) [23] classification.

Data were processed using Microsoft Excel (Microsoft Corporation ${ }^{\mathrm{TM}}$, Redmond, Washington, United States of America), analyzed using the Statistical Package for Social Science (SPSS Inc., Chicago, Illinois, United States of America) version 17, and expressed as absolute values, percentage, mean, and standard deviation. Pearson's Chi-squared test was used to determine the association between the sports characteristics (training
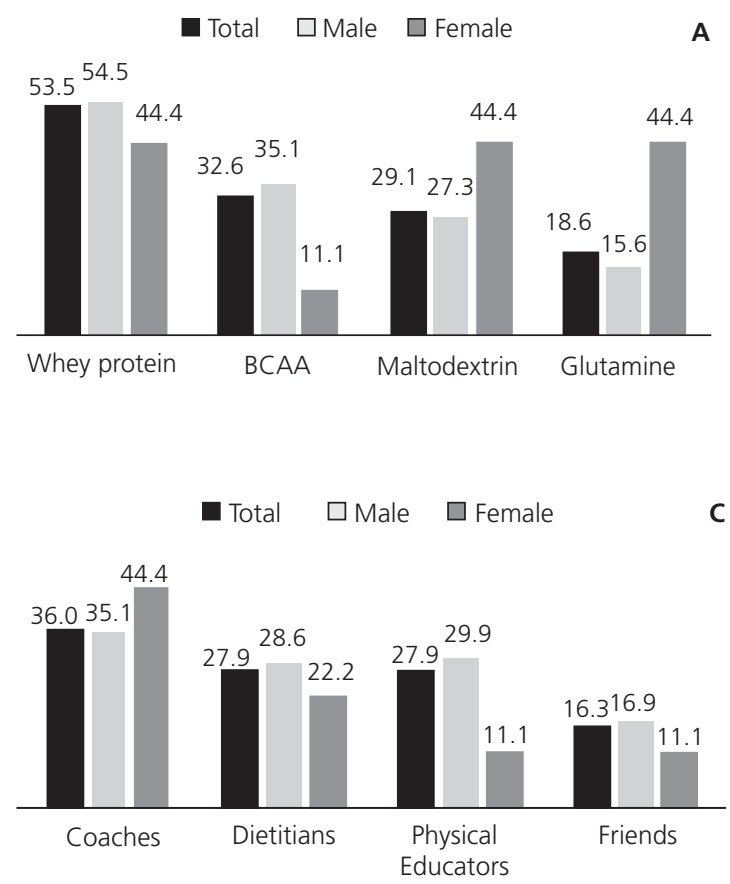

volume, training phase, sports type) and the variables related to the use of dietary supplements (most commonly consumed supplements, most frequently mentioned reasons for consumption, recommendation sources, and amount of supplements consumed), considering $p<0.05$ as the level of statistical significance.

\section{RE S U L T S}

The questionnaire showed that 86 out of the 182 athletes (47.3\%) evaluated used dietary supplements. Among the athletes who consumed dietary supplements, $70.0 \%$ were aged 25-29 years. A total of 37 types of dietary supplements were reported, with an average intake of $3.0 \pm 2.5$ supplements per athlete (ranging from 1 to 12 ). Table 1 shows the main characteristics of the study participants. Table 2 shows the amount and types of dietary supplements mentioned by the athletes.

Figure 1 shows the main characteristics of the dietary supplement use among athletes. Figure $1 \mathrm{~A}$ indicates the four most commonly
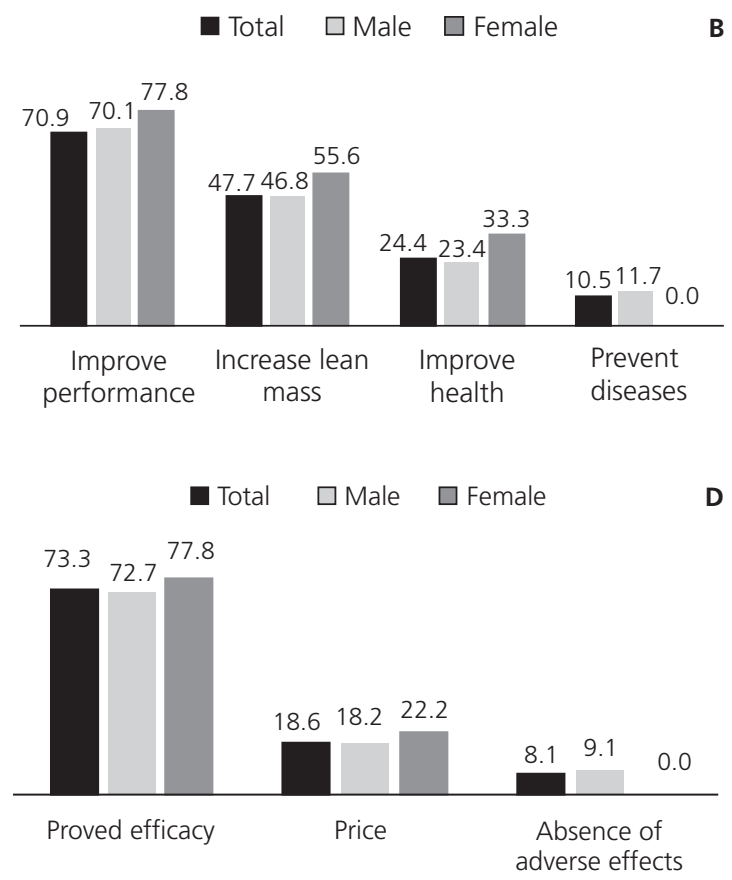

Figure 1. Dietary supplement consumption characteristics according to gender $(\mathrm{N}=86)$ and expressed in percentages. Cuiabá (MT), Brazil (2013-2015). 
consumed dietary supplements: whey protein, Branch Chain Amino Acids (BCCA), maltodextrin, and glutamine. The most frequently mentioned reasons for their consumption among the athletes were to improve performance, increase lean mass, improve overall health, and prevent illnesses (Figure 1B).

The main recommendation and information sources were coaches, dietitians, physical educators, and friends (Figure 1C). A considerable proportion of athletes (16.3\%) reported that they consumed dietary supplements on their own. The main factors influencing the decisions to buy these supplements included proved efficacy, price, and absence of adverse effects (Figure 1D). Among the athletes who consumed dietary supplements, $61.6 \%$ reported consuming 1 to 2 supplements daily, 23.3\% consumed 3 to 4 supplements, and $15.1 \%$ consumed five or more supplements

Table 3 shows that the consumption of whey protein and glutamine was different between the different sports, and the athletes in individual sports were the greatest consumers. There was a significant difference between the preparatory phase and the consumption of maltodextrin and glutamine. There was a significant difference between individual sports and the reason 'improve health'.
Table 1. Main characteristics of study participants $(\mathrm{N}=182)$. Cuiabá (MT), Brazil (2013-2015).

\begin{tabular}{|c|c|c|c|c|}
\hline \multirow{2}{*}{ Characteristics } & \multicolumn{2}{|c|}{ Male $(n=151)$} & \multicolumn{2}{|c|}{ Female $(n=31)$} \\
\hline & $\mathrm{M}$ & DP & $M$ & $\mathrm{DP}$ \\
\hline Height (m) & $1.76 \pm$ & 0.07 & $1.60 \pm$ & $=0.10$ \\
\hline Weight (kg) & $77.80 \pm$ & 12.90 & $54.10 \pm$ & $=6.80$ \\
\hline \multirow[t]{2}{*}{ Age (years) } & $24.20 \pm$ & 7.00 & $20.60 \pm$ & $=7.60$ \\
\hline & $n$ & $\%$ & $n$ & $\%$ \\
\hline \multicolumn{5}{|l|}{ Age group } \\
\hline 14 to 19 & 46 & 30.5 & 17 & 54.8 \\
\hline 20 to 24 & 41 & 27.1 & 6 & 19.4 \\
\hline 25 to 29 & 39 & 25.8 & 4 & 12.9 \\
\hline$\geq 30$ & 25 & 16.6 & 4 & 12.9 \\
\hline \multicolumn{5}{|l|}{ Education level } \\
\hline$\leq 8$ years & 14 & 9.3 & 7 & 22.6 \\
\hline$>8$ years & 136 & 90.1 & 24 & 77.4 \\
\hline \multicolumn{5}{|l|}{ Employed } \\
\hline Yes & 68 & 45.0 & 11 & 35.5 \\
\hline No & 82 & 54.3 & 20 & 64.5 \\
\hline \multicolumn{5}{|l|}{ Category } \\
\hline Amateur & 71 & 47.0 & 14 & 45.2 \\
\hline Professional & 78 & 51.7 & 15 & 48.4 \\
\hline \multicolumn{5}{|c|}{ Hours of training per week } \\
\hline$\leq 8$ hours & 39 & 25.8 & 9 & 29.0 \\
\hline$>8$ hours & 106 & 70.2 & 22 & 71.0 \\
\hline \multicolumn{5}{|c|}{ Competitive level } \\
\hline Municipal & 35 & 23.2 & 8 & 25.2 \\
\hline State & 47 & 31.1 & 11 & 35.5 \\
\hline National & 51 & 33.8 & 9 & 29.0 \\
\hline International & 15 & 9.9 & 2 & 6.5 \\
\hline \multicolumn{5}{|c|}{ Federated athlete } \\
\hline Yes & 116 & 76.8 & 25 & 80.6 \\
\hline No & 23 & 15.2 & 3 & 9.7 \\
\hline Do not know & 9 & 6.0 & 3 & 9.7 \\
\hline
\end{tabular}

Table 2. Most frequently mentioned dietary supplements by the athletes ( $n=86)$. Cuiabá (MT), Brazil (2013-2015).

\begin{tabular}{|c|c|c|c|c|c|}
\hline Proteins/Amino acids & $(\mathrm{N}=101)$ & Carbohydrates & $(\mathrm{N}=32)$ & Vitamins & $(N=20)$ \\
\hline Whey protein & 46 & Maltodextrin & 25 & Multivitamin/mineral & 12 \\
\hline BCAA & 28 & Waxy maize & 3 & Vitamin C & 5 \\
\hline Glutamine & 16 & D-ribose & 1 & Vitamin B & 2 \\
\hline Albumin & 4 & Not specified & 3 & Vitamin $\mathrm{B}_{12}$ & 1 \\
\hline Carnivor & 3 & & & & \\
\hline Casein & 1 & & & & \\
\hline Leucine & 1 & & & & \\
\hline Arginine & 1 & & & & \\
\hline Beta-alanine & 1 & & & & \\
\hline Minerals & $(\mathrm{N}=15)$ & Ergogenic aids & $(\mathrm{N}=18)$ & Other supplements & $(\mathrm{N}=33)$ \\
\hline Multivitamin/mineral & 12 & Creatine & 12 & Thermogenic & 9 \\
\hline Chromium & 1 & Caffeine & 4 & Fatty acids & 6 \\
\hline Chromium Picolinate & 1 & Guaraná powder & 2 & Pre-workout & 4 \\
\hline \multirow[t]{3}{*}{ Calcium } & 1 & & & Pro-hormones & 4 \\
\hline & & & & Sports drinks & 4 \\
\hline & & & & Others (not specified) & 6 \\
\hline
\end{tabular}


Table 3. Dietary supplementation practice according to the type of sports and the training phase $(n=86)$. Cuiabá (MT), Brazil (2013-2015).

\begin{tabular}{|c|c|c|c|c|c|c|c|c|c|c|c|c|}
\hline \multirow{3}{*}{$\begin{array}{l}\text { Consumption } \\
\text { characteristics }\end{array}$} & \multicolumn{4}{|c|}{ Type of sports } & \multirow{3}{*}{$p$} & \multicolumn{6}{|c|}{ Training phase } & \multirow{3}{*}{$p$} \\
\hline & \multicolumn{2}{|c|}{ Individual } & \multicolumn{2}{|c|}{ Team } & & \multicolumn{2}{|c|}{ Preparatory } & \multicolumn{2}{|c|}{ Active Rest } & \multicolumn{2}{|c|}{ Competitive } & \\
\hline & $\mathrm{n}$ & $\%$ & $\mathrm{n}$ & $\%$ & & $\mathrm{n}$ & $\%$ & $n$ & $\%$ & $\mathrm{n}$ & $\%$ & \\
\hline $\begin{array}{l}\text { Most commonly } \\
\text { consumed supplements }\end{array}$ & 55 & 64.0 & 31 & 36.0 & 0.14 & 59 & 68.6 & 11 & 12.8 & 16 & 18.6 & 0.19 \\
\hline Whey protein & 36 & 78.3 & 10 & 21.7 & 0.03 & 32 & 69.6 & 6 & 13.0 & 8 & 17.4 & 0.95 \\
\hline BCAA & 19 & 67.9 & 9 & 32.1 & 0.60 & 18 & 64.3 & 4 & 14.3 & 6 & 21.4 & 0.84 \\
\hline Maltodextrin & 13 & 52.0 & 12 & 48.0 & 0.14 & 11 & 44.0 & 4 & 16.1 & 10 & 40.0 & $<0.05$ \\
\hline Glutamine & 16 & 100.0 & 0 & 0.0 & $<0.001$ & 12 & 75.0 & 4 & 25.0 & 0 & 0.0 & $<0.05$ \\
\hline \multicolumn{13}{|l|}{ Most frequently mentioned } \\
\hline \multicolumn{13}{|l|}{ reasons } \\
\hline Improve performance & 42 & 68.9 & 19 & 31.1 & 0.14 & 42 & 68.9 & 7 & 11.5 & 12 & 19.7 & 0.82 \\
\hline Increase lean mass & 29 & 70.7 & 12 & 29.3 & 0.21 & 28 & 68.3 & 6 & 14.6 & 7 & 17.1 & 0.86 \\
\hline Improve health & 36 & 55.4 & 29 & 44.6 & $<0.05$ & 12 & 57.1 & 5 & 23.8 & 4 & 19.0 & 0.21 \\
\hline Prevent diseases & 7 & 77.8 & 2 & 22.2 & 0.48 & 5 & 55.5 & 2 & 22.2 & 2 & 22.2 & 0.60 \\
\hline \multicolumn{13}{|l|}{ Recommendation sources } \\
\hline Coaches & 25 & 80.6 & 6 & 19.4 & $<0.05$ & 25 & 80.6 & 2 & 6.5 & 4 & 12.9 & 0.18 \\
\hline Dietitians & 17 & 70.8 & 7 & 29.2 & 0.41 & 17 & 70.8 & 4 & 16.7 & 3 & 12.5 & 0.95 \\
\hline Physical educators & 12 & 50.0 & 12 & 50.0 & 0.09 & 16 & 66.7 & 1 & 4.2 & 7 & 29.2 & 0.12 \\
\hline Friends & 11 & 78.6 & 3 & 21.4 & 0.21 & 10 & 71.4 & 2 & 14.3 & 2 & 14.3 & 0.89 \\
\hline Amount of supplements & & & & & $<0.001$ & & & & & & & 0.35 \\
\hline \multicolumn{13}{|l|}{ consumed daily } \\
\hline 1 to 2 & 25 & 47.2 & 28 & 52.8 & & 40 & 75.5 & 5 & 9.4 & 8 & 15.1 & \\
\hline 3 to 4 & 17 & 85.0 & 3 & 15.0 & & 11 & 55.0 & 3 & 15.0 & 6 & 30.0 & \\
\hline$\geq 5$ & 13 & 100.0 & 0 & 0.0 & & 8 & 61.5 & 3 & 23.1 & 2 & 15.4 & \\
\hline
\end{tabular}

Note: Values expressed as $n$ (\%). Information regarding athletes who are supplement users.

BCAA: Branch Chain Amino Acids.

Athletes in individual sports were more likely to seek advice about using supplements from their coaches. In the competitive phase, physical educators seem to be the main sources of information; during the rest phase, dietitians were the most sought after professionals by the athletes, and they were the only source of information for the athletes undertaking highvolume training, as shown in Table 4. There was an association between high-training volume and getting advice from friends. Concomitant use of four dietary supplements was more common among athletes in individual sports.

\section{DISCUSSION}

The present study is one of the few studies carried out in Brazil addressing the profile of dietary supplement use among athletes. Our findings reveal that almost half of the athletes investigated use dietary supplements. Moreover, multiple dietary supplement intake is more common among athletes in individual sports, who also pointed out their coaches as the main source of supplement recommendation. The prevalence of supplement use observed in the present study corroborate the findings reported in previous studies carried out in Norway and Iran [12,17].

One third of the sample was composed of adolescent athletes, which may have influenced the prevalence of consumption in this study, consistent with the findings of McDowall's [13], who found lower prevalence of consumption of dietary supplement in this age group. Other factors related to the different methodologies (type of instruments) used, such as the definition 
Table 4. Dietary supplementation practice according to training volume ( $n=86)$. Cuiabá (MT), Brazil (2013-2015).

\begin{tabular}{|c|c|c|c|c|c|}
\hline \multirow{3}{*}{ Consumption characteristics } & \multicolumn{4}{|c|}{ Training volume } & \multirow{3}{*}{$p$} \\
\hline & \multicolumn{2}{|c|}{ High } & \multicolumn{2}{|c|}{ Low/Moderate } & \\
\hline & $\mathrm{n}$ & $\%$ & $\mathrm{n}$ & $\%$ & \\
\hline Total values & 72 & 83.7 & 9 & 10.4 & 0.05 \\
\hline \multicolumn{6}{|l|}{ Most commonly consumed supplements } \\
\hline Whey protein & 39 & 84.8 & 4 & 8.7 & 0.82 \\
\hline BCAA & 24 & 85.7 & 2 & 7.1 & 0.75 \\
\hline Maltodextrin & 20 & 80.0 & 3 & 12.0 & 0.81 \\
\hline Glutamine & 12 & 75.0 & 2 & 12.5 & 0.41 \\
\hline \multicolumn{6}{|l|}{ Most frequently mentioned reasons } \\
\hline Improve performance & 51 & 83.6 & 6 & 9.8 & 0.87 \\
\hline Increase lean mass & 36 & 87.6 & 4 & 9.8 & 0.42 \\
\hline Improve health & 20 & 95.0 & 1 & 4.8 & 0.23 \\
\hline Prevent diseases & 9 & 100.0 & 0 & 0.0 & 0.18 \\
\hline \multicolumn{6}{|l|}{ Recommendation sources } \\
\hline Coaches & 27 & 87.1 & 2 & 6.5 & 0.66 \\
\hline Dietitians & 23 & 95.8 & 0 & 0.0 & $<0.05$ \\
\hline Physical educators & 20 & 83.3 & 1 & 4.2 & 0.15 \\
\hline Friends & 7 & 50.0 & 5 & 35.7 & $<0.05$ \\
\hline Amount of supplements consumed daily & & & & & 0.31 \\
\hline 1 to 2 & 44 & 83.0 & 5 & 9.4 & \\
\hline 3 to 4 & 15 & 75.0 & 4 & 20.0 & \\
\hline$\geq 5$ & 13 & 100.0 & 0 & 0.0 & \\
\hline
\end{tabular}

Note: Information regarding athletes who are supplement users.

BCAA: Branch Chain Amino Acids.

of dietary supplements, the particular time period of consumption, and the different sports evaluated, may also explain the variation in the prevalence of dietary consumption among the different studies. However, our findings and those available in the literature show that dietary supplementation is a frequent practice among professional athletes across a range of sports [13].

In the present study, the most frequently used supplements by the athletes were whey protein, BCAA, maltodextrin, and glutamine. According to Kreider et al. [22], dietary supplements can be classified according to their efficacy and safety, and whey protein and maltodextrin are considered to be apparently effective and safe supplements for muscle growth and performance improvement, respectively. BCAA is also considered effective in promoting muscle mass increase and performance improvement. However, glutamine is considered to be apparently ineffective. Our results suggest that athletes have sought supplements with proved efficacy, a finding similar to that reported by Lun et al. [7].

The results obtained in present study differ from many others that have found that vitamins, minerals, and/or multivitamin/minerals were the most frequently consumed supplements among athletes $[2,5,6,8,17]$. Although $17.5 \%$ and $23.3 \%$ of the athletes investigated consumed minerals and vitamins, respectively, these supplements were not included in the list of the four most frequently used supplements. Other studies with Brazilian athletes have shown that the pattern of dietary supplement use is controversial, and they reported that multivitamin/mineral supplements [24] and maltodextrin [20] were the most frequently consumed. The difference between their findings and ours may be related to the fact that some athletes do not consider multivitamins, vitamins, minerals, and/or sports drinks as dietary supplements [14]. 
Another hypothesis is the motivation for supplement consumption. In the studies that found that vitamin and mineral supplements were the most frequently mentioned supplements, the main reason for consumption was health related $[5,15]$. In the present study, the major motives for supplement use among athletes were to improve performance $(78.0 \%)$ and increase lean mass $(47.7 \%)$. These findings can partly explain why we found that whey protein was the most commonly consumed supplement, in agreement with the findings reported by Wiens et al. [3], Sundgot-Borgen et al. [12], and Giannopoulou et al. [16].

It is worth highlighting that the use of dietary supplements related to health issues may indicate that athletes do not believe that their regular diet provides the nutrient level that is sufficient to meet their daily nutritional needs [5]. In the present study, the most frequent reason mentioned by the athletes who are not supplement users was that there was no need for supplementation. These findings corroborate those of other studies, Rodek et al. [18] and Nieper [25]. Lack of knowledge was another reason for not consuming supplements, which is in agreement with previous studies that found that the greater the knowledge of supplementation the more willing the athlete is to use supplements [2].

Consistent with the results of other studies $[8,12,16]$, we found that coaches are the primary source supplement recommendation for most athletes, and dietitians were their second main source of information, corroborating the findings among Saudi Arabian athletes [26] and Brazilian cyclists [20]. However, in most studies cited here, dietitians are not among the main three information sources $[5-7,18]$.

With regard to the type of sports, our findings corroborate those reported by Giannopoulou et al. [16], who found that individual athletes consumed more supplements. According to Suzic Lazic et al. [27] and Bishop [28], a possible reason is that even a small advantage can make a difference in individual sport outcomes, unlike team sports, in which individual performance often does not reflect the performance of the team. Therefore, supplement intake is expected to be higher among athletes in individual sports. In the present study, 16.3\% of the athletes reported seeking information for themselves, which is consistent with the results of a previous study carried out with Japanese and Korean judoists, and many athletes consider price more important than product efficacy. These two findings indicate that economic factors can influence the choice of supplements by athletes.

Although supplementation may imply high monthly costs, the average supplement intake per athlete was $3.0 \pm 2.5$, as reported in the literature [29]. Multiple supplementation practice, i.e., the concomitant use of five or more supplements was observed in $15.3 \%$ of the athletes evaluated and was higher among athletes in individual sports. It is noteworthy that the two most frequently consumed supplements (whey protein and BCAA) have the same purpose, i.e., both are muscle building supplements. This shows that unnecessary multiple supplementation practice could be avoided if athletes sought guidance from a qualified professional.

One of the great risks of taking dietary supplements without proper guidance is positive doping. Several studies with professional athletes have reported that the use of dietary supplements is an initial step towards the use of illegal performance-enhancing drugs (or "doping") and/or for illicit substance use [10,30]. Backhouse et al. [10] found that "doping" use was threeand-a-half times more prevalent in dietary supplement users compared with nonusers.

To our knowledge, this is one of the first studies carried out in Brazil with athletes from different sports. The present study also analyzed dietary data regarding supplement consumption, establishing a profile of the consumption of these products. However, the present study showed some limitations. The first one is related to the cross-sectional design, which allows the research to make associations between events only, 
preventing cause-and-effect inferences. The definition of dietary supplement is another limiting factor since it may make comparison between studies difficult. Furthermore, the questionnaire may not reflect the reality of the participants, leading to under- and overestimates; however, this type of instrument has been widely used in studies in this field $[2,8]$. Kappa coefficient of 0.72 indicated a strong agreement between the two methods used to evaluate dietary supplement use: the questionnaire and the 24-hour dietary recall interview, which was conducted on two non-consecutive days in the same week the questionnaire was administered.

The results of this study point to the need for nutritional education among coaches and athletes. It is expected that professional experience and the relationship between the coach and the athlete are factors of great influence on dietary supplement use. However, it is very important to consider that many coaches do not have enough knowledge to give advice or recommend diets and use of supplements [30], which actually should be done by qualified professionals. If on the one hand, dietary supplementation may benefit mainly athletes undertaking physical training with high energy requirements or that have pre-existing nutritional deficiencies and hyper- or hypocaloric diets, on the other hand, the concomitant use of several supplements may lead to drug-nutrient or nutrient-nutrient interactions, and thus can be harmful to athletes' health or affect their performance in the short, medium, or long term [25].

Therefore, our findings reinforce the importance of the presence of a professional who hold a sports nutrition certification and thus can develop personalized dietary strategies that meet the needs of the athletes, while considering efficacy aspects, the risk and benefits of these supplements to their health, and the risk of a positive doping test. It is worth mentioning that many Brazilian athletes or sports clubs cannot afford to have a qualified professional on their own or as part of their staff, respectively. In these cases, a consultant dietitian should be hired to train and educate coaches and athletes, without incurring costs associated with a specialized technical staff.

\section{CONCLUSION}

The present study showed that a large proportion of the athletes evaluated use dietary supplements following their coaches' recommendation. The most frequently mentioned reasons for the consumption of supplements were to improve performance and increase lean mass. Therefore, we believe there is an association between these most common purposes and the fact that whey protein was the most commonly consumed supplement since it promotes muscle growth. The consumption profile also revealed multiple supplementation practice and demonstrated that nutritional education is essential for this specific population.

\section{A C KNOWLEDGMENTS}

The authors are grateful for the financial support provid by Coordenação de Aperfeiçoamento de Pessoal de Nivel Superior and Conselho Nacional de Desenvolvimento Científico e Tecnológico.

\section{CONTRIBUTORS}

All authors participated in all phases of the research.

\section{REFERE NCES}

1. U.S. Food and Drug Administration. Dietary Supplement. Silver Spring (MD): U.S. Food and Drug Administration; 2016 [cited 2015 Nov 9]. Available from: http://www.fda.gov/Food/Dietary Supplements/default.htm

2. Dietz $P$, Ulrich R, Niess $A$, Best R, Simon P, Striegel $H$. Prediction profiles for nutritional supplement use among young German elite athletes. Int J Sport Nutr Exerc Metab. 2014;24(6):623-31. https://doi. org/10.1123/ijsnem.2014-0009 
3. Wiens K, Erdman KA, Stadnyk M, Parnell JA. dietary supplement usage, motivation, and education in young, Canadian athletes. Int J Sport Nutr Exerc Metab. 2014;24(6):613-22. https://doi.org/10. 1123/ijsnem.2013-0087

4. Froiland K, Koszewski W, Hingst J, Kopecky L. Nutritional supplement use among college athletes and their sources of information. Int J Sport Nutr Exerc Metab. 2004;14(1):104-20. https://doi.org/ 10.1123/ijsnem.14.1.104

5. Braun H, Koehler K, Geyer H, Kleiner J, Mester J, Schanzer W. Dietary supplement use among elite young German athletes. Int J Sport Nutr Exerc Metab. 2009;19(1):97-109. https://doi.org/10. 1123/ijsnem.19.1.97

6. De Silva A, Samarasinghe Y, Senanayake D, Lanerolle P. Dietary supplement intake in nationallevel Sri Lankan athletes. Int J Sport Nutr Exerc Metab. 2010;20(1):15-20. https://doi.org/10.1123/ ijsnem.20.1.15

7. Lun V, Erdman KA, Fung TS, Reimer RA. Dietary supplementation practices in Canadian highperformance athletes. Int J Sport Nutr Exerc Metab. 2012;22(1):31-7. https://doi.org/10.1123/ijsnem. 22.1.31

8. Diehl K, Thiel A, Zipfel S, Mayer J, Schnell A, Schneider S. Elite adolescent athletes' use of dietary supplements: Characteristics, opinions, and sources of supply and information. Int J Sport Nutr Exerc Metab. 2012;22(3):165-74. https://doi.org/10. 1123/ijsnem.22.3.165

9. Kandel DB. Stages and pathways of drug involvement: Examining the gateway hypothesis. Cambridge: Cambridge University Press; 2002.

10. Backhouse SH, Whitaker L, Petróczi A. Gateway to doping? Supplement use in the context of preferred competitive situations, doping attitude, beliefs, and norms. Scand J Med Sci Sports. 2013;23(2):244-52. https://doi.org/10.1111/j. 1600-0838.2011.01374.x

11. Maughan RJ. Quality Assurance issues in the use of dietary supplements, with special reference to protein supplements. J Nutr._2013;143(11):1843S-7S. https://doi.org/10.3945/jn.113.176651

12. Sundgot-Borgen J, Berglund B, Torstveit MK. Nutritional supplements in Norwegian elite athletes: Impact of international ranking and advisors. Scand J Med Sci Sports. 2003;13(2):138-44. https://doi. org/10.1034/j.1600-0838.2003.10288.x

13. McDowall J. Supplement use by young athletes. J Sports Sci Med. 2007;6(3):337-42.

14. Molinero O, Márquez S. Use of nutritional supplements in sports: Risks, knowledge, and behavioural-related factors. Nutr Hosp. 2009 [cited 2014 Feb 15];24(2):128-34. Available from: http:// www.redalyc.org/articulo.oa?id=309226744006

15. Kim J, Lee N, Lee J, Jung S-S, Kang S-K, Yoon J-D. Dietary supplementation of high-performance Korean and Japanese judoists. Int J Sport Nutr Exerc Metab. 2013;23(2):119-27. https://doi.org/10.11 23/ijsnem.23.2.119

16. Giannopoulou I, Noutsos K, Apostolidis N, Bayios I, Nassis GP. Performance level affects the dietary supplement intake of both individual and team sports athletes. J Sports Sci Med. 2013;12(1):190-6.

17. Darvishi L, Askari G, Hariri M, Bahreynian M, Ghiasvand R, Ehsani S, et al. The use of nutritional supplements among male collegiate athletes. Int J Prev Med. 2013;4(Suppl.1):S68-72.

18. Rodek J, Sekulic D, Kondric M. Dietary supplementation and doping-related factors in high-level sailing. J Int Soc Sports Nutr.2012;9(1):51. https://doi.org/10.1186/1550-2783-9-51

19. De Rose EH, Feder MG, Pedroso PR, Guimarães AZ. Uso referido de medicamentos e suplementos alimentares nos atletas selecionados para controle de doping nos Jogos Sul-Americanos. Rev Bras Med Esporte. 2006;12(5):239-42. https://doi.org/10.15 90/S1517-86922006000500003

20. Cazal MDM, Alfenas R. Dietary practices of Brazilian mountain bikers before and during training and competition. Arch Med Deporte. 2013 [cited 2015 Jan 16];30(2):83-90. Available from: http:// femede.es/documentos/OR_01_Dietary_154.pdf

21. Nogueira FRS, Souza AA, Brito AF. Prevalência do uso e efeitos de recursos ergogênicos por praticantes de musculação nas academias brasileiras: uma revisão sistematizada. Rev Bras Ativ Fis Saúde. 2013;18(1):16-30. https://doi.org/10.12 820/2317-1634.2013v18n1p16

22. Kreider RB, Wilborn CD, Taylor L, Campbell B, Almada AL, Collins R, et al. ISSN exercise and sport nutrition review: Research and recommendations. J Int Soc Sports Nutr. 2010;7(7):1-43. https://doi. org/10.1186/1550-2783-7-7

23. World Health Organization. Physical status: The use and interpretation of anthropometry. Geneva: WHO; 1995 [cited 2014 Dec 11]. Technical Report Series, $n^{\circ}$ 854. Available from: http://whqlibdoc. who.int/trs/WHO_TRS_854.pdf?ua=1

24. Nogueira JA, Da Costa TH. Nutrient intake and eating habits of triathletes on a Brazilian diet. Int J Sport Nutr Exerc Metab. 2004;14(6):684-97. https:// doi.org/10.1123/ijsnem.14.6.684

25. Nieper A. Nutritional supplement practices in UK junior national track and field athletes. Br J Sports 
Med._2005;39(9):645-9. https://doi.org/10.1136/ bjsm.2004.015842

26. Aljaloud SO, Ibrahim SA. Use of dietary supplements among professional athletes in Saudi Arabia. J Nutr Metab. 2013;2013:1-7. https://doi. org/10.1155/2013/245349

27. Suzic Lazic J, Dikic N, Radivojevic N, Mazic S, Radovanovic D, Mitrovic N, et al. Dietary supplements and medications in elite sport: Polypharmacy or real need? Scand J Med Sci Sports. 2001;21(2):260-7. https://doi.org/10.1111/j.1600-08 38.2009.01026.x

28. Bishop D. Dietary supplements and team-sport performance. Sports Med. 2010;40(12):995-1017. https://doi.org/10.2165/11536870-000000000-0 0000

29. Geyer H, Parr M, Koehler K. Nutritional supplements crosscontaminated and faked with doping substances. J Mass Spectrom. 2008;43(7):892-902. https://doi.org/10.1002/jms1452

30. Sousa M, Fernandes MJ, Moreira P, Teixeira VH. Nutritional Supplements Usage by Portuguese Athletes. Int J Vitam Nutr Res. 2013;83(1):48-58. https://doi.org/10.1024/0300-9831/a000144

Received: April 15, 2016

Final version: October 26, 2016

Approved: November 25, 2016 
